(C) 2012

Свстаф'єва В. О., доктор ветеринарних наук

Полтавська державна аграрна академія

\title{
ТОКСИЧНІ ВЛАСТИВОСТІ ІНСЕКТОАКАРИЦИДНОГО ПРЕПАРАТУ ЕКТОСАНУ
}

\section{Рецензент - доктор ветеринарних наук А. А. Замазій}

\begin{abstract}
Отримані дані щуодо токсичної характеристики інсектоакарицидного препарату ектосану. Лікарський засіб у терапевтичній концентрації $(0,13 \%$ водний розчин) не проявляв місчевоподразнюючої та резорбтивної дій на двох видах тварин (кролі, щури). За місцевою дією на шкіру лабораторних тварин за одноразового його нанесення ектосан відносився до нульового класу і характеризувався відсутністю подразнюючої дї. В групі білих щурів у однієї тварини через 15 хвилин після обробки препаратом реєстрували занепокоєння, слабку еритему та помірний свербіж, які зникали через 30 хвилин після їх появи.
\end{abstract}

Ключові слова: ектосан, токсичні властивості, лабораторні тварини.

Постановка проблеми. За останні 10 років накопичено значний досвід застосування у практиці ветеринарної медицини різних протипаразитарних лікувальних засобів. Вони відносяться до різних класів сполук і, як правило, більш ефективні проти окремих паразитів. Упродовж останнього часу у фахівців ветеринарної медицини значно зросла потреба в інформації про нові хімічні засоби, що зареєстровані в Україні й застосовуються як акарициди $[1,3]$.

Аналіз основних досліджень і публікацій, у яких започатковано розв'язання проблеми. Нині провідні фармацевтичні фірми світу для виготовлення інсектоакарицидних препаратів широко використовують синтетичні піретроїди (дельтаметрин, зетациперметрин, перметрин, тетрометрин, фламетрин, циперметрин тощо). Засоби, які мають у своєму складі ціангрупу (циперметрин, дельтаметрин), більш активні у рідких формах, але володіють місцевоподразнюючими властивостями і є слабкими алергенами $[5,7]$.

Піретроїди - препарати, високотоксичні для членистоногих і малотоксичні для тварин, оскільки повільно всмоктуються через шкіру в кров і містять інгредієнти, що сповільнюють даний процес. Саме тому ці препарати не кумулюються в організмі. До того ж вони легко і на тривалий час прилипають до шерсті тварин, що сприяє іiі високій активності проти паразитів. Механізм дії піретроїдів зводиться до порушення співвідношення між іонами натрію та калію на мембранах оболонок клітин паразита. При цьому блокується передача нервових імпульсів через ганглії периферичних нервів кліщів та комах, що призводить до їх паралічу, а пізніше й загибелі. Одна 3 основних переваг піретроїдів - висока вибіркова токсичність, ступінь якої для теплокровних тварин неоднакова $[4,6]$.

Мета і завдання досліджень. Метою роботи було вивчення токсикологічної характеристики інсектоакарицидного препарату ектосану на лабораторних тваринах, а саме: місцевої дії хімічної речовини на шкіру, шкірно-резорбтивного впливу при одноразовому нашкірному нанесенні, місцевоподразнюючої дії на слизову оболонку ока.

Матеріали і методи досліджень. Дослідження проводили протягом 2010-2011 років на базі наукової лабораторії кафедри паразитології та ветеринарно-санітарної експертизи Полтавської державної аграрної академії. Були проведені досліди 3 апробації нового інсектоакарицидного препарату ектосану (НВФ «Бровафарма», Україна). Він являє собою маслянисту прозору рідину світло-жовтого кольору 3 легким специфічним запахом і містить комбінацію двох діючих основ: альфаметрину (альфа-циперметрин) i піпероніл-бутоксиду.

Визначали вплив ектосану на шкіряні покриви лабораторних тварин (місцеву й шкірнорезорбтивну дії за одноразового нашкірного нанесення) та на слизові оболонки очей. Для виявлення місцевої дії ектосану експеримент проводили на восьми кролях білої масті (2-3 кг) та восьми білих щурах (180-200 г). Препарат наносили на шкіру тварин у розведеннях 1:750, $1: 600,1: 500$. Реакцію реєстрували по закінченню експозиції (4 год) через одну та 16 годин після одноразової аплікації, виражаючи в балах згідно 3 методикою А. І. Заіченко (1979) [2]. Шкірно-резорбтивну дію ектосану за одноразового нашкірного застосування вивчали на двох видах тварин (лабораторні щури, кролі). Препарат наносили на шкіру в розведенні 1:750. 
Упродовж двох тижнів вели спостереження за загальним станом і поведінкою тварин. Облік реакції проводили, враховуючи показники летальності або за розвитком клінічних ознак інтоксикації. Вивчення месцевоподразнюючого впливу ектосану на слизові оболонки очей проводили на восьми кролях. Кожній тварині у кон'юнктивальний мішок правого ока 3 піпетки вносили одноразово 2-3 краплі розчину препарату (1 : 750). Ліве око слугувало контролем - у нього вносили 2-3 краплі дистильованої води. Реакцію спостерігали візуально через 30 хв; 1, 5, 24 та 48 годин.

Результати дослідження. Аналізуючи отримані дані (див. табл.), можна зазначити, що водний розчин ектосану в розведенні 1 : 750 відносився до нульового класу за ступенем вираженості подразнюючої дії на шкіру лабораторних тварин за одноразового його нанесення. Характеризувався відсутністю подразнюючої дії на шкіру лабораторних тварин упродовж експерименту.

Аналогічні дані отримали й у процесі дослідження препарату в розведені 1 : 600. В усіх дослідних тварин після нанесення водного розчину ектосану через одну та 16 годин не реєстрували зміни кольору й ознак набряку на шкірі в ділянці аплікації. Застосовуючи препарат у розведенні 1 : 500 на шкіру лабораторних тварин, у одного кроля спостерігали слабку еритему в ділянці аплікації відразу після закінчення експозиції лікарського засобу (4 години). При цьому шкіра набувала візуально рожевого забарвлення, що за оцінкою еритеми відповідало 1 балу. Набряку на оброблених ділянках шкіри протягом досліду не виявляли. Ознаки еритеми зникали через одну годину після закінчення експозиції й не виявлялися протягом досліду.

У дослідній групі білих щурів у процесі аплікації їм на шкіру ектосану в розведенні $1: 500$ також реєстрували у двох тварин появу слабкої еритеми після закінчення експозиції препарату. Шкіра візуально набувала рожевого забарвлен- ня, проте набряку не було. Вираженість еритеми у цих тварин оцінювалася в 1 бал. Через годину ознаки гіперемії шкіри в щурів у ділянці аплікації хімічної речовини зникали і протягом експерименту більше не виникали.

Оцінка ступеня еритеми і набряку сумувалася для кожної дослідної тварини, після чого підраховували середню оцінку вираженості подразнюючої дії ектосану для групи експериментальних тварин. Для дослідних кролів та щурів, яких використовували в експерименті, середній сумарний бал вираженості еритеми і величини набряку становив: за розведення $1: 500-0,2 ; 1: 600-0$; $1: 700$ - 0. Відповідно отриманим результатам, водний розчин ектосану в розведенні $1: 500$ мав слабкоподразнюючу дію й відносився до першого класу (за ступенем вираженості подразнюючої дії на шкіру лабораторних тварин за одноразового його нанесення), в розведенні 1 : 600 і 1 : 750 характеризувався відсутністю подразнюючої дії та відносився до нульового класу.

Результати вивчення шкірно-резорбтивної дії ектосану за одноразового нашкірного нанесення кролям та білим щурам вказували на відсутність проявів інтоксикації у тварин. Упродовж двотижневого спостереження всі дослідні кролі мали нормальний апетит, гладкий і пухнастий волосяний покрив, їх поведінка не змінювалася. В групі білих щурів у однієї тварини через 15 хвилин після обробки препаратом реєстрували занепокоєння, появу слабкої еритеми та помірний свербіж. Такі клінічні ознаки зникали через 30 хвилин після їх появи. До кінця експерименту видимих змін інтоксикації більше не спостерігали. В інших дослідних щурів упродовж досліду будь-яких змін у вигляді гіперемії шкіри, набряку, занепокоєння не реєстрували. У ході вивчення видової сприйнятливості встановлено, що у 12,5 \% щурів реєстрували ознаки інтоксикації (свербіж, слабка еритема шкіри), які тривали 30 хвилин після обробки тварин лікарським засобом.

\section{Ступінь порушення шкіряного покриву лабораторних тварин за дії водних розчинів} ектосану $(n=8)$

\begin{tabular}{|c|c|c|c|c|c|}
\hline $\begin{array}{c}\text { Розведення } \\
\text { препарату }\end{array}$ & $\begin{array}{c}\text { Вид } \\
\text { тварин }\end{array}$ & $\begin{array}{c}\text { Середній сумарний бал } \\
\text { вираженості еритеми і } \\
\text { величини набряку }\end{array}$ & $\begin{array}{c}\text { Середній } \\
\text { бал }\end{array}$ & $\begin{array}{c}\text { Вираженість } \\
\text { подразнюючої дії }\end{array}$ & Клас \\
\hline \multirow{2}{*}{$1: 500$} & кролі & 0,1 & 0,2 & $\begin{array}{c}\text { слабкоподраз- } \\
\text { нююча дія }\end{array}$ & 1 \\
\cline { 2 - 3 } $1: 600$ & щури & 0,3 & 0 & $\begin{array}{c}\text { відсутність подраз- } \\
\text { нюючої дії }\end{array}$ & 0 \\
\cline { 2 - 3 } & кролі & 0 & 0 & $\begin{array}{c}\text { відсутність подраз- } \\
\text { нюючої дії }\end{array}$ & 0 \\
\hline \multirow{2}{*}{$1: 750$} & кролі & 0 & 0 & & \\
\cline { 2 - 3 }
\end{tabular}


За результатами отриманих даних вивчення впливу ектосану на слизові оболонки очей кролів можна зазначити, що протягом експерименту не виявлено видимої реакції з боку слизової оболонки очей кролів, що свідчить про відсутність місцевоподразнюючої дії препарату. Упродовж досліду стан обох очей був ідентичним. Слизова оболонка мала блідо-рожеве забарвлення, 3 ознаками незначної ін'єкції судин, без сльозових витікань та набряку.

\section{БІБЛІОГРАФІЯ}

1. Малинін О. А. Досягнення з фармакології і токсикології в ІЕКВМ / О.А.Малинін, В.Д. Шуляк, В. В. Волощенко // Ветеринарна медицина: міжвід. темат. наук. зб. - Х., 1998. - Вип. 75. C. $159-166$.

2. Оценка воздействия вредных химических соединений на кожные покровы и обоснование ПДУ загрязнений кожи / [Методические указания МЗ СССР]. - М., 1980. - 23 с.

3. Сидоров И. В. Лекарственные вещества в птицеводстве / И. В. Сидоров. - М. : Колос, 1976. $240 \mathrm{c}$.

4. Стринадкин П. С. Саркоптоидозы животных и меры борьбы / П. С. Стринадкин // Проблемы энтомологии и арахнологии: научн.-техн. бюлл.

\section{Висновки:}

1. За місцевою дією на шкіру лабораторних тварин за одноразового нанесення інсектоакарицидний препарат ектосан відноситься до нульового класу.

2. Ектосан у терапевтичній концентрації $(0,13 \%$ водний розчин) не виявляє резорбтивної дії за одноразового його нанесення на шкіру двох видів лабораторних тварин (кролі, щури) й характеризується відсутністю подразнюючої дії.

ВНИИВЭА. - Тюмень, 1989. - Вып. 34. - С. 86-93. 5. Стринадкин П. С. Эктомин при саркоптозах животных / П. С. Стринадкин, А. К. Метелица, А. Н. Давлетшин // Ветеринария. - 1991. - № 1. C. $48-49$.

6. Тимофеев Б. А. Биорекс - новое противочесоточное средство на основе циперметрина / Б. А. Тимофеев, Г. В. Кирюткин, В. О. Бондаренко // Ветеринария. - 1997. - № 3. - С. 54-58.

7. Фролов Б. А. Эффективность применения препаратов на основе синтетических пиретроидов и ФОС при энтомозах и арахнозах животных / Б. А. Фролов, И. К. Казакова, В. И. Букштыков // Ветеринария. - 1994. - № 7. - С. 31-33. 